Ђорђе Н. Кебара*

Универзитет у Крагујевцу

Филолошко-уметнички факултет
821.163.41-93.09-31 Басара C.

https://doi.org/10.18485/analiff.2019.31.2.2

Originalni naučni rad

Primljen: 15.07.2019

Prihvaćen: 11.09.2019

\title{
ДЕКОНСТРУКЦИЈА ИСТОРИОГРАФИЈЕ И ИДЕОЛОШКОГ МИШЉЕЫА У ДЕЛУ ФАМА О БИЦИКЛИСТИМА СВЕТИСЛАВА БАСАРЕ
}

Предмет истраживања претпоставља разоткривање принципа и стратегија конструкције теме историографије у роману. Разматраћемо пародичне облике писања и метафикционални карактер представљања историјског мишљења. Наративна стратегија Светислава Басаре говори о подривању идеолошких система, порицању хијерархије и укидању институционализованог мишљења. Успоставља се критички однос према историјској условљености мишљења. Аутор дела Фама о биииклистиима претпоставља други, метафикционални свет, који конструише на месту укрштања интертекста. У погледу плуралитета текстова, дело је предочено као збирка текстова, часопис или зборник. Преовладавајући метод односи се на подривање владајућих система, али и на самопорицање сопствених исказа. Претпостављени модел света тиче се хаотичне структуре, а она је супростављена лажној (институционализованој) историографској свести, која истину маскира фантомском творевином, чинећи симулакруме. У том погледу учестала је метафора огледала.

Кључне речи: историографија, метафикција, интертекст, плуралитет текстова, институција, истина, симулакрум, огледало

\section{УВОД}

Анализа рада подразумева увид у дистинкцију појмова „историја” и „историографија”, у први план постављајући семантичка својства историографије. Дистинкција између два појма односи се на значење „историје” као науке о прошлости, а „историографије”, као науке која проучава историју историјске науке. Односно, разматра се критички аспект историографије који је уочљив у Басарином делу, преиспитивање историје, не као прошлости него као историографс-

*_cowboydzo@yahoo.com 
Ђорђе Н. Кебара

ке науке у погледу западног мишљења. Узимамо у обзир и то да на терминолошком плану, а у контексту водећих постмодерних аутора и теоретичара постмодернизма (Фуко, Хачион, Бодријар), заступљена је употреба појма „историографија” - управо означавајући критику историјске условљености мишљења.

\section{ПОЛИТИЗАЦИЈА ИСТОРИОГРАФСКОГ ДИСКУРСА}

Наслов романа Фама о бициклистиима садржи жанровску одредницу која се односи на фаму. Појам „фама” читамо у значењу непроверене гласине, нечега недоказаног методолошким или логоцентричним разматрањем истиносних судова. Лексема „фама” етимолошки води порекло од римске богиње вести. Носи значење вести или говоркања, проноси се реч о нечему, али њена истинитост је непроверена, а може бити и кажа - препричавање. Референцијалном одредницом жанровског типа С. Басара уводи читаоце у метафикционални вид приповедање чије полазиште је у подривању постојано формираних логоцентричних система. Као једини начин супростављања структурисаној парадигми изабрана је фама. Њу тумачимо као постмодернистички роман-метафикцију, а постмодернизам у фикцији јесте историографска метафикција (Hačion, 1996: 9). На тај начин, метафикционално у интертексту, шири се гласина о илузионистичким истинама и лажним системима.

Постмедернистички вид наратолошког и жанровског конструисања књижевног дела, говори нам о плуралитету стилова. Природа подривања Западног мишљења посредством филозофских текстова

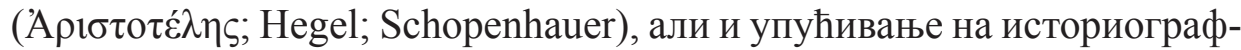
ске студије - Пропаст Запада (O. Spengler), као и друге културолошке и књижевне феномене (хришћанство; мистицизам; психологија; детективски роман), говоре о многострукости текстова и таквом читању дела. Басара формира књижевни облик зборника текстова, чиме долази у могућност да мањим техничким јединицама (поглављима; чланцима; параграфима; стубцима), али и наративним облицима (апокриф; писмо; вест; чланак у часопису), означи метапоетичко виђење историје. Она се протеже од грађења Вавилонске куле до позног социјализма у Југославији. Текстови који се односе на различите историјске периоде или метафикционалне целине, прате атмосферу пре- 
дочене теме (библијски дискурс; апокриф у средњем веку; иследничка прича).

Доминантна тема која је присутна у делу односи се на питање формирања историјске свести човечанства. У том погледу представићемо историографију као о критички поглед на историјску стварност, али и као критику реалитета који не постоји као такав. Унутар уводног поглавља романа, које фигурира као предговор допуњеног издања 2007. године, Басара претпоставља један вид становништва изверзираног идеолошким мишљењем, а историју или свест, која је наметнута, тумачи као ону која се креће већ уходаним токовима (2007: 7). Ентитет који утиче на развој иделогизма је друштво, а оно што друштво нормира није стварност него илузија - „оне (друштвенополитичке заједнице) су огледало” (2007: 150). Поетско решење за такво становништво - имагинарно, представљено је метафоричко-алузивно као пројекат „Велике луднице” (пројекат као симбол институционалне надоградње). Аутор ће касније у тексту признати да је модел за „Велику лудницу” била стара заједничка држава народа у региону Социјалистичка Федеративна Република Југославија.

У предговору допуњеног издања, чини се осврт на наивни аспект већинског становништва које представља подршку институционализованим системима. Заправо, културно-историјска парадигма целокупног становништва формирана је на тај начин, а историја као таква не постоји већ је само историја лакрдијаштва (2007: 8-9). У духу нове епохе, Басара истиче постојање искључиво многоструких псеудосистема, истинитост сваке институционализације подложна је преиспитивању. У том погледу, на питање институције, као предмета оспоравања у постмодернизму, Л. Хачион (L. Hutcheon) у Поейиции иосиимодернизма наводи:

Šta, zapravo, postmodernizam osporava? Pre svega ispituju se institucije: od medija do univerziteta, od muzeja do pozorišta [...] Prirodne ili iluzionističke konvencije umetnosti često su razgolićene da bi izazvale institucije u kojima su našle dom - i smisao." (1996: 25-26)

Историја каквом је данас видимо, искључиво је фрагментарна и недовршена, а хаос је једини предложени систем у роману. У 
Ђорђе Н. Кебара

том погледу, Басара наводи ауторе који су померили аспект историографског приказивања (псеудо)стварности, између којих се налазе: О. Шпенглер (1880-1966); Р. Генон (René Guénon - 1886-1951); Х. Ортега и Гасет (José Ortega у Gasset - 1883-1955). Шпенглер је очевиднији пример историографа; Ортега и Гасет је есејиста, представља слободнији вид изражавања близак фикцији; Генон је учењак најдаље постављен од традиционализма, његова изучавања приближавају се метафизици, симболизму и иницијацији. У делу романа, означеном психоаналитичким дискурсом, наглашава се истраживање интуиције и синхроницитета ${ }^{1}$ (Басара, 2007: 116). Р. Генон је, на овој скали, најдаљи је од догматски условљене свести - представља прекршај табуа и прекорачење границе. У духу образованог карактера, Басара наводи ове ауторе као обавезну лектиру.

Након тога направљен је методолошки оквир за афирмацију мистификованих теорија. Теорија „историографске метафикције јасно потврђује да постмодернизам делује унутар сложене институционалне и дискурзивне мреже елиптичких, званичних, масовних, популарних култура" (Нас̌ion , 1996: 45). Као парадокс тајних удружења и апсурд јавног мнења, аутор Фаме уводи идеју тајног реда „Бициклиста ружиног крста". Уочљив је референцијални слој тајних удружења попут слободних зидара и масона на синхронијском плану историографске пројекције романа, али и помодност формирања удружења или говоркања о непознатим и необјашањивим догађајима, на плану историје - оса дијахроније. Као референцу на помодност таквих аналошких формација (2007: 189), Басара ће у роману навести рад Јохана Хојзинге (Johan Huizinga - 1872-1945), изучаваоца средњег века, који је написао књигу Јесен у среgњем веку (1919). Присутно је пародирање

1 Сихроницитет је појам који конституише К. Г. Јунг (С. G. Jung - 1875-1961). Деловање сихроницитета претпоставља „смислене случајности” или искуство у свесном стању човековог ума када почињу да се примећују обрасци. Синхроницитет је индивидуално субјективно стање, као и унутрашње стање сна, материјализује се изнутра, али добија оспољашњену артикулацију. Синхроницитет је модел двају принципа присутних у Фами о бициклистиима. Супростављене су две стране, идео-

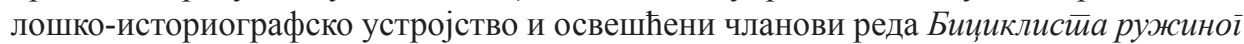
крсй .

2 Помодарство у западном средњовековном витештву огледа се у витешким редовима најзаступљеније у оквиру властеле Западне Европе. Почетак моралног 
витешких редова, односно историографске банализације тајних удружења. Каже се у роману: „тако је глас о нечувеним безакоњима ђавоље дружине, која је сама себе назвала Peg мале браће, доспео и до краљевског престола" (2007: 56) Басара се пародично односи према поимању историјских догађаја и мистеријског преувеличавања, говорећи ,бициклисти су криви за све”.

Уопштавања историјских прилика и помодни однос према стварности, која је лажна пошто је институционализована, у роману добија облик етикете или фразема помодности и псеудокатегоризација савремених прилика. Личности (писац одбија да их назива личностима), које су одговорне за креирање доминирајуће парадигме, назване су аутором дела „хегелијанском заједницом духова” (Басара, 2007: 11). Хегелијанска заједница духова односи се, у сваком случају, на филозофски рад Г. В. Ф. Хегела (1770-1830), на његову дијалектику и Феноменолоїuје gyxa (1807). Идеолошко мишљење у роману подразумева критику солипсизма ${ }^{3}$. На крају предговора постаје уочљива референцијална конструкција дела, историја мислилаца одговорних за постанак западне дијалектике (филозофи; историчари; уметници), на парадигматској оси, добијају пресек у виду испољавања савремене мисли, на синтагматској оси. Тиме се приказ огледа дубљим историографским и метафикционалним описом, али и критичким коментаром.

\section{ПОДРИВАЊЕ ИНСТИТУЦИОНАЛИЗМА}

Кључним историјским тренутком - прича у легенди, приповедач поставља грађење Вавилонске куле. Особина градитељства (у метафикционалном слоју романа има шире симболичко значење) по-

банализовања настао је међу бурбонским племенитим породицама правилом да сваки племић ствара породични ред у славу куће и породичног имена, као врсту личне пратње која добија нов и егзотични облик. Највећи од тих редова био је Peg Злайної руна, а онда су уследили многи мањи редови незнатног значаја, па и симболике, један од тих редова звао се Реg Бояљикавої йрасейа.

3 Солипсизам претпоставља филозофско начело: веровање да су постојани само особа и индивидуално искуство. Заснован је на доктрини да је индивидуално целокупна реалност, а све што се налази изван, своди се на осете, опажаје и представе - субјективни идеализам. Хегелијанском принципу чулног и опредмећеног идеализма, Басара супроставља поунутрашњене мистеријске духовне феномене. 
стављена је као опозиција људској таштини. Особина таштине представља се као основни узрок човековог пада, како је рекао пророк Данило - Omnia vanitas. Некада су људи говорили истим језиком, али се Бог разљутио и поделио језик на мноштво различитих језика, како се људи међусобно не би разумели и поново почели да праве кулу. Служећи се методом пародирања, Басара уводи у причу тајно удружење Бициклиста који покушавају де реконструишу кулу у облику „Велике луднице”.

Историја човечанства представљена је у Фами као историја ждрања, блуди и људске таштине. Лудница је осмишљена као место у коме би се налазили преступници - један вид паклених кругова на земљи, у роману именовани „симулакруми пакла” (Басара, 2007: 362). Лудница ће у књизи бити названа и борделом. Историјски референцијални слој Велике луднице проналазимо у податку о пројекту установе која ће бројати до двадесет милиона становника, као и у ауторовом запису - модел произилази из бивше југословенске републике. Аутор на тај начин пародира већ институционализовану стварност чврстог политичког режима. Користећи се фигуративим говором, подрива га и реконструише, постављајући нови институционализовани систем, који приповедно више одговара.

Истицањем блудне природе и човекове палости, Басара структурно прави опозиције духовно/телесно; унутрашње/спољашње; вера/истина. Наративна стратегија у дѐлу такве је природе да неконвенционалним културним феноменима потире владајуће системе мишљења - попут мистичне заљубљености у бога (хришћанство; тибетански мистици) наспрам историографске истинитости - на пародијски начин дестабилишу се конвенције (Hačion , 1996: 49). У тренуцима када такви ставови прете да заузму доминантну позицију у дискурсу, Басара их пародира - долази до самопорицања сваке иделогије. Тако су испољена постмодернистичка начела, како истиче Л. Хачион: „Postmodernizam je protivrečan fenomen koji upotrebljava i zloupotrebljava, gradi i ruši sve pojave koje izaziva" (1996: 16). He допушта се владајућа позиција центра него је наглашена улога читања историје са маргине. Са овог аспекта, читамо апокрифну ${ }^{4}$

4 Апокриф је средњовековни неканонски спис библијске тематике. Иако су апокрифи тематски били везани за библијске приче, приступ проблему често је 
епизоду о фикционалном краљу Карлу Ружном ${ }^{5}$ и његовом саветнику Гроссману.

Карло Ружни пише историју унапред, кршећи логоцентричне принципе, али и предочавајући историју као метафикцију - измишљене факте који говоре о сопственој постојаности као стварности - што је псеудоистина. Фама о бициклистиима је роман који у структури садржи ауто-иронијски карактер, као преиспитивање сопствених конструкција - саморефлексивни је роман. Постмодернизам је иронијско преиспитивање историје (Нас̌ion , 1996: 19) На тај начин, Карло Ружни ће се пожалити како све што он говори, Гроссман увече брише са документа - струже, а на маргинама оставља коментаре који потиру његове речи. Истовремено је обједињено неколико значајних топоса постмодернистичке поетике:

1) Гроссман који оставља запис на маргини краљевог текста представља топос многоструких аутора; 2) Гроссман, као средњовековни записивач, својеврсна је историографска референца (топос средњовековног записивача пример је чувара историје/текста, често је у сагласности са мотивом библиотекара у постмодерној поетици, нпр. Име руже; Хазарски речник); 3) Маргина која брисањем главног текста замењује центар - нема текста и све је текст - истина као релативизам. Према Л. Хачион пародија преиспитује идеје порекла или оригиналности (1996: 29); 4) Избрисани главни текст упућује на палимпсест - брисана, штављена кожа; 5) Избрисани текст је топос изгубљеног текста - пародијски приказана изгубљена истина. Карло Ружни - референца на Карла Великог, представљен је у апокрифном поглављу као неко ко нема оца, иронијски објашњавајући да на тај начин превазилази едипов комплекс: „Немам оца, никоме ни ја нећу

имао другачије аспекте од званичне библијске приче. Како су писани изван званичних монашких преписивачких школа и манастирских институција, а притом мењајући перспективу поимања појединих догађаја-легенди, били су забрањивањи у црквеној употреби - неканонизовани. Поетски посматрано, у Фами о бициклисиимма, апокриф је прекорачење институције.

5 Карло Ружни алузивно-пародична је референца на оца франачке државе Карла Великог (742-814). Поетско преименовање краљевског епитафа „Велики” у „Ружни” говори о десакрализацији или деградирању до сфере унижавања. Пародично, човек је у роману окарактерисан као конформиста, а унижавање не постоји, осим у имену фикционалног краља који потире званичну историографију. 
бити отац. И квит" (Басара, 2007: 20). Наведена реплика представља мотив укидања центра, традиције, али и историографско-дијалектички условљеног мишљења. Питање идентитета у Фами о бициклис$\bar{u}$ има може се читати као аутопародијски моменат романа. C једне стране, подривају се системи, а концепти оца и центра деконструишу ce, с друге стране, концепт идентитета опонира лажној иделогији историографије. Каже се: „Онај ко нема оца, нема објекат са којим би се идетификовао; између њега и предака (историје) зјапи празан простор - ништавило" (Басара, 2007: 104). Присутна је афирмација историје као прошлости или традиције, а она је градивни део човековог бића.

Тема институционализованог знања проналази место у апокрифном поглављу исто тако. Острвивши се на Гроссмана, Карло Ружни говори о његовој сујети, на језичком плану представљена је тако да се име Гроссман правилно пише са два -с. Његов саветник има докторат са универзитета у Упсали - наговештава се да је диплома лажна - као што су институције и звања лажна. Басара потире системе институционализованог мишљења, супроставља им моделе табуисаних феномена у духу средњовековне епохе (нихилизам; јерес), пресељава краља из замка у крчму за блуднике, а престо му је голгота (Басара, 2007: 30-31). Пародија спроведена у роману културолошког је карактера: „Postmoderna parodija koristi svoje istorijsko sećanje, svoju estetsku introverziju, da bi ukazala da je ovaj tip samorefleksivnog diskursa uvek nerazmrsivo povezan sa društvenim diskursom." (Hačion, 1996: 69)

Уочљив је приступ унижавања - сфера високог спуштена је и девалвирана до простих сталежа. То представља референцу на средњовековно монашко унижавање као принцип истинитог, али маргиналног и неприхваћеног - у погледу већинског става. Научници жуде за функцијама и звањима, прерађујући исте текстове у непрекидно зачараном кругу - Circulus vitiosus, по Басари су особе без онтолошког покрића (2007: 32). Карло Ружни, пародично демитологизовани отац франачке државе, пише историју унапред чиме је потире изнутра. Унутрашњи вид деловања историје као поетске метафикције, попут архетипа, који је хаотичне структуре, можемо пронаћи у студији Л. Хачион Поеииика йосиимоgернизма: „Pо mom shvatanju, poetika ne bi trebalo po pitanju istorije da traži mesto između teorije i prakse, već bi pre trebalo da traži mesto unutar njih." (1996: 39) 
Унутрашњи принцип - према моделу религиозног мистика, супростављен је спољашњем принципу. Басара, у епистоларном делу романа, истиче речи апостола Томе „Оно што изнесеш, то ће те спасити; оно што не изнесеш, то ће те уништити” (2007: 112). На тај начин упућује се на доминантну позицију лажног које је сакривено, а пројекција стварности јесте уметничка и дијалектичко-текстолошка обрада лажног - псеудоистина. Водећи се принципом духовног у роману, Басара предочава узроке одвајања од Бога: „Бог је увек унутра. Ми смо напољу. Погрешна пројекција.” (2007: 42) Присутан је пародијски однос према темељима цивилизације Запада, када се говори о одласку у Америку или на Запад, каже се „уместо вертикално, кренуће хоризонтално” (2007: 48). Писац подлаже иронизацији сваки иделошки принцип, логоцентрични систем, еуклидовску перцепцију простора - систем се деконструише.

Упућује се на мислиоце Западне Европе који тумаче хришћанство као историјску грешку. Критика таквих ставова исказана је речима да „несрећа Европе није у томе што се христијанизовала, како то злосрећно тумачи млади Хегел, него управо у томе што се није довољно христијанизовала" (2007: 121). На тај начин Басара тумачи владајућу историографску свест као антропоцентричну или аутономну од Бога. Човек је окренутошћу од Бога и оспољашњеношћу остао јеретик духом, а његова настојања су паганска - центар је постао маргина - духовни принцип, а маргина постаје центар - јеретичка природа. У том духу узвикује се: све је таштина!

\section{СИМУЛАКРУМИ И СИМУЛАЦИЈЕ ИСТИНЕ}

Принцип хијерархијске уређености и законитог чињеничог следа додатно је наглашен мотивом законика. Карло Ружни, будући краљем, начиниће документ који ће метафикционлану историју легитимисати члановима закона. Басара је доследан пародијском моделу подривања историографије, па посредством Карла Ружног истиче неважност текстолошког садржаја таквог документа. Истакунута су два члана законика: 1) Мучење и тамновање су привилегије, то је сигуран пут у царство небеско; 2) Не чини другом оно што не желиш да чине теби (2007: 33). Након прве две тачке законика „остатак, десет томо- 
ва, испуњен је мрљама. Симулакрумима 6 слова. Песмама трубадура" (2007: 33). Поред деградираног својства историографије, на овом месту је уочљиво и самопорицање и деконструкција претходно назначаваних идеолошких ставова о духовности. Ново доба институционализоване историје писац назива „Нова Европа”, а текстови које она производи представљају симулацију истине или симулакруме.

Насупрот иделошкој, религиозно-догматској, вредносној основи, појам вере код Басаре носи функцију опозиције. Категорија којој вера у Фами о бициклистиима опонира јесте инквизиција западног хегеловског мишљења. Вера је супростављена егзактношћу историографских чињеница. Теоријско разматрање вере, као културолошког феномена, Басара преузима од О. Шпенглера, не као телеологију знања него као негацију егзактности. У трећем тому књиге Пройасй зайaga наводи се:

„Nikada nijedna vera ne može izmeniti svet, niti ijedna činjenica ikada može opovrgnuti veru. Nema mosta između [...] hoda istorije i božanskog poretka sveta u čijoj je građi reč za najviši slučaj kauzalnosti: opredeljenje. To je poslednji smisao onoga trenutka u kome smo stajali - jedan prema drugome Isus i Pilat. U jednome svetu, onom istoriskome, Rimljanin je Galilejca razapeo na krst [...] U drugom svetu, Rim je pao pod prokletstvo, a krst je postao jemstvo spasenja.” (Špengler, 1989: 242)

Јукстапозицију, изнету у цитату, поетски употребљава Басара, покушавајући да истакне вечну испреплетеност два супростављена принципа - историјски (земаљски) и онострани (небески). У роману се истиче „нисам чињеница, само верујем да постојим” (Басара 2007: 36). Приметна је реконструкција филозофске максиме француског рационалисте Р. Декарта ${ }^{7}$ (1596-1650) - мислим дакле постојим. Фран-

6 Латински појам - означава сан, привиђење, слику симулацију. Ж. Бодријар (J. Baudrillard - 1929-2007), у књизи Симулакруми и симулащија (1981), тумачи језички знак као дијалектичку симулацију истине. Бодријар каже: „Тој се убитачној моћи супроставља моћ представа као дијалектичка моћ, видљиво и разумљиво преношење стварног. Сва Западна вера и поверење ангажовали су се у том подухвату репрезентације: да се један знак може замењивати за смисао и да нешто [...] служи као подлога за ту замену.” (Bodrijar, 1991: 9)

O апсурду дијалектичког мишљења говори Декартова (R. Descartes) макси- 
цуски мислилац на основу физичког (чињеничног) деловања доказује егзактност сопственог постојања. Басара, на основу концепта вере у детерминисаност света, поништава чињенице, које су пролазне у зависности од владајуће иделогије. Писац истиче „оно што протиче између није време, протичу само чињенице” (Басара, 2007: 37). Појам духа, као не-материје сагласне са небеским устројством, историографски је недоказив. Управо из еуклидовски недоказивог феномена духа, Басара му признаје истинитост, а представнику хегелијанског мишљења говори „поричем да ти постојиш” (2007: 37).

Истина коју наводимо као афирмишућу категорију у роману о бициклистима, не може се тумачити као научна или егзактна, пошто се таква истина опонира. У том погледу, у роману фигурира синтагма „истина писца” (Басара, 2007: 37-38), а такво полазиште подударно је са разматрањима Ц. Тодорова (1939-2017) у тексту Фикције и исииине (1984). Тодоров разматра два типа истине, обеледањујућу истину (егзактну; читамо историографску) и истину више-мање (поетска истина) (2000: 36). Као примере појмовних одредница Тодоров наводи две приче, прву о становништву острва Формоза ${ }^{8}$ (Европљанима представља не-доместицирано дивљаштво), а друга прича говори о открићу Новог света - Америке9. Супростављеност двају типова истина Тодоров тражи у узроцима именовања новог континента Америком. Два су истраживача одлазила у Америку, Америго Веспучи (1454-1512), по

мa Cogito ergo sum (мислим дакле постојим). Значајна ставка у прилог теми јесте исходиште картезијанске мисли у средњовековној хришћанској изреци Тертулијана (Tertullianus) Credo quia absurdum (верујем јер је апсурдно) - дијалектички опозитна полазишта. Апсурд је додатно наглашен природом латинског језика. Мртви језици, како Басара каже за историографске текстове, латински језик након пропасти Римског царства и нестанка његових говорника престаје бити употребљаван. Употреба латинског језика међу средњовековним мислиоцима и потоњим филозофима и научницима односи се на конструкцију псеудолатинизама у терминолошке сврхе - у питању је лажни језик.

8 Прича о Форможанима односи се на Мемоаре (1764) мистификатора Псалманазара (псеудоним; фиктивни лик - непознато порекло), а у фокусу расправе је поетски језик као лаж или фалсификат на историографском плану.

9 Прича о открићу америке говори о поетском језику или језику писца као помереној перспективизацији истине на историографском плану. Временски раскорак између два историјска догађаја износи око два и по века, а разлика је настајала и начинима поимања истине. 
коме континент добија име, одлази први, али не као вођа експедиције ${ }^{10}$. Кристифор Колумбо (1451-1506) као вођа експедиције одлази у Америку после Веспучија. Након двоструких експедиција, оба истраживача остављају списе о појединостима становништва и континента. Историографски посматрано Колумбо је као вођа експедиције именован проналазачем ${ }^{11}$ (Todorov, 2000: 43), а самим тим и континент је могао понети назив Колумбија. Карактеристика је и та што континенти добијају назив по имену Америго, а не по презимену што би било опште правило проналазака. Тодоров анализира узроке поетске природе (2000: 434). Веспучи је у списима већу пажњу посвећивао читаоцима, давао је примере који су подстицали њихову машту ${ }^{12}$. Колумбо је, с друге стране, био дистанциранији од читалаца, а описи су били дескриптивније ${ }^{13}$ природе. Ц. Тодоров истиче да је Америка један од ретких примера именовања где је поетска истина победила наспрам историографских чињеница (2000: 52). Посебно је значајан детаљ метонимијске номинализације где је преузето име истаживача за именовање новог света.

По питању симулацијске природе историографских описа или подражавања стварности, у Фами фигурира симболика огледала. Имагинарно друштво Бициклиста ружиног крста постало је свесно по-

10 Прва експедиција Америга Веспучија (Amerigo Vespucci), по неким истраживачима, датира из 1497. године (као члан, не као вођа), али она није историографски утврђена. Тодоров, као прво путовање, наводи експедицију из 1503. године, а списи, које Веспучи оставља у виду писама, објављивани су 1506. и 1507. године под насловима Mundus Novus, као и Quatuor Navigationes. Тодоров наводи критеријум да је Веспучи био свестан проналаска новог континента. Колумбо (С. Columbus) je, с друге стране, веровао да се 1497. године искрцао у Индију.

11 Званично становиште је да је Колумбо открио Америку.

12 Узбудљива афирмација Новог света; постављање читаоца на пиједестал; пише да би задобио славу, а не новац; настоји да забави Лоренца де Медичија (Lorenzo de' Medici) и Фирентинце - имагинарни спис хуманизма и ренесансе; сексуалне теме - преступ табуа. Тодоров наводи опис индијанских жена: „Indijanske žene su veoma pohotne [...] one stavljaju otrovne životinje na penise svojih partnera; posle ujeda, penis raste sve dok ne dostigne neverovatne razmere, tako da na kraju pukne i muškarci postaju evnusi” (Todorov, 2000: 48-49). Интригантни описи, више имагинарни него историографски, донели су Веспучијевим списима већу популарност него писма Кристифора Колумба.

13 Географски описи; природа; портрети становника; напомене о Индијанцима; уверавање шпанског краљевског пара о богатсву и плодности земље. 
грешне перспективизације стварности. Они, наизглед насумичним акцијама, покушавају да промене идеолошку прадигму - ломљење сатова и огледала. Истичу се три симбола историографског мишљења: „Без огледала, сатова и мачева нема историје” (Басара, 2007: 81). Симболика огледала односи се на имитативно дејство, умногостручавање стварности, али тај одраз је илузија. Огледало „осликава привид, рефлекс, сенка [је] стварности" (Басара, 2007: 138). Илузија коју оставља огледало широког је опсега - захвата читаво друштво, постмодернистички посматрано, она гради лавиринт. Према Басари историја представља „дворану огледала у којој се не зна који је прави, а који је лажни лик” (2007: 82).

Сатови симболишу време, а време је представљено као релативизам. Идеолошко мишљење намеће размишљање у периодизацијама и хијерархијском следу, али Басара истиче хаос као једину не-структуру која је стварна. Сагласно концепту хаоса, представљен је конепт сна. Бициклисти тренирају контролу сна, а сан је истинска сфера човековог деловања. Сан представља живот, хаотичан је и стихијски.

Мачеви симболишу историју насиља. Историографија је, у том погледу, дефинисана као оружије идеолошког мишљења. М. Фуко (М. Foucault 1926-1984) такву улогу историографије тумачи као конституисање позиције моћи ${ }^{14}$. Писана историја је историја ратова, а прекрштени мачеви хералдички су симбол периода рата.

Карактеристикама постмодернистичког негирања, Басара пориче постојање хуманизма, али, како је пародијско преображавање, по природи ствари, двоструко усмерено, може се говорити и о критици идеализма, који је периодизацијом хуманистичког доба уништава појам хуманости. Опозиција хуманости представљена је технолошким добом и техницизмом. У делу романа означеног жанровским осо-

14 Критика историграфије, код Басаре, често је критика политичке идологије. Он је дезавуише кроз историографски дискурс који је симбол апарата (идеолошког, политичког, државног) који, попут Фукоове идеје моћи, има могућнност успостављања репресије. Фуко, у Истиорији луgила у доба класииизма (1961), истиче: „УПраво су за ту моралну обавезу задужени његови управитељи, те им је додељен цео правни и материјални апарат репресије: 'сви они имају моћ власти, управљања, вођења, полиције, право суђења, укоравања и кажњавања'; а да би обавили тај задатак на располагање им се стављају 'стубови срама, вратни окови, затвори и подземне станице““. (1980: 68) 
Ђорђе Н. Кебара

бинама часописа наводи се речник технологије - тумачење појмова савременог света. Технологија у Фами очигледна је опозиција хуманости, а хуманост је изгубљена још у човековој палости са Адамом и Евом, Вавилонском кулом и развојем идеолошке парадигме - истиче ce Diferentia specifica технолошког доба (Басара, 2007: 136). Изражени су метафоричност, езоповски језик, говор шифара, опредмећен поглед на свет, антихуманост, антисоцијалне особености друштва (2007: 137). У извесном погледу Басарин пародијски однос према техницизму као да је антиципирао општа места социјалне располућености, која постаје интезивнијом проширеним утицајем сајбер простора и интернет комуникације, посебно путем друштвених мрежа.

На послетку, намеће се експлицитан опис идеологизације и институционализованог мишљења, које је проширено писаним текстовима (историографија; наука; књижевност), а он се тиче теоретисања. Аналитички вид теоретисања методолошки су и логички постављене максиме којима се манипулише истиносним судовима. Како истиче Басара у Фами о Бициклистиима „у сваку глупост се може уградити логички систем"15 (2007: 291). Такав метод окарактерисан је „приручником људске лудости доведене на ниво науке", а Басарина књига представља пародију у облику „обести, сотије ${ }^{16}$, пеана ${ }^{17}$, видика, луде куће ума, антикњиге” (2007: 397). Техника пародирања у роману, пародијске и самопародијске особености, сведоче о ауторовом моделу подривања логоцентричних система и теоретичке условљености дијалектичког мишљења. Жанровска многострукост упућује на постмодернистичко поигравање садржајем и формом. Облик романазборника, стилизованом анализом историјских збивања, својеврсни је историјски каламбур. Принцип путем ког Карло Ружни пише историју у напред, има пародијску антитетичну намену. Пошто се истори-

15 Читамо као тип аутопародије. Фама, као врста књижевно-вербалног израза, покушај је да се из хаоса и фиције направи уређена конструкција, хијерархично условљена (књига, роман, жанр).

16 Порекло лексеме „сотија происходи из лудости. Сотија је сатирична драмска врста настала у другој половини 15. века на територијама Француске, Холандије, Данске и Енглеске.

17 Пеан је врста песме захвалнице или радоснице. У почетку је била посвећивана богу Аполону. 
ографско мишљење посматра као регресија духа, Басара карактерише историју као точак који се окреће уназад.

\section{ЗАКЉУЧАК}

У раду смо показали како се наративна стратегија С. Басаре у Фами о бищиклисиичма односи на жанровску колажираност и пародију дијалектичког мишљења, као и схоластичке текстуалности. Елементарна метода Басариног писања тиче се подривања историјског дискурса и институционализованог мишљења. У погледу такве текстуалности, аутор креира хиперреференцијално дело, цитирајући најзначајније филозофе, писце, историчаре и научнике Западне Европе, а у корист мистификовања историје. Хегелијанском типу солипсистичког индивидуализма, супроставља се поунутрашњени поглед, афирмативан у погледу мистицизма и спиритуализма. Примарна функција романа је пародија, а „истина историје” замењена је „истином метафикције" - метафиктивни роман.

Карактеристика наративности романа је алузивна инстанца приповедачке форме. Басара, критикујући историографски конструисано мишљење савремене јединке, трансформише дискурс у критику политичке идеологије, јер историја човечанства историја је ратова Bellum omnium contra omnes est vita hominis. Модел пародирања опонира са аутопародирајућим својстима ауторовог текста.

Сваки идеолошки, логоцентрични и еуклидовски начин перцепције у роману изложен је иронизацији. Критика друштва, код Басаре, критика је историографије, која је представник псеудоистине. Истини историграфског дискурса, аутор супростваља истину писца, која је попут тодоровљеве „истине више-мање” ближа човеку, више него истина дијалектичког система. Истина писца, опет, самообмањујућа је, метафикционална и подложна иронизацији и пародији као и дијалектика. Басарин роман представља подривање идеолошког мишљења, али га карактерише и аутопародирајуће својство. Основни принципи се заснивају на постмодернистичкој стратегији метафикције и мистификације историје човечанства. Роман Фама о бициклисйима перифрастични је пастиш историографске и научне парадигме у постмодернистичком кључу - реч је о поступку карневализације дискурса као свеобухватне пародије књижевног текста. 


\title{
ЛИТЕРАТУРА
}

Басара, С. (2007). Фама о биииклисииима. Београд: Дерета.

Bodrijar, Ž. (1991). Simulakrumi i simulacija, Novi Sad: Svetovi.

Fuko, M. (1980). Istorija ludila u doba klasicizma. Beograd: Nolit.

Hačion, L. (1996). Poetika postmodernizma: istorija, teorija, fikcija. Novi Sad: Svetovi.

Todorov, C. (2000). Kultura: časopis za teoriju i sociologiju kulture i kulturnu politiku, 100, 33-58.

Špengler, O. (1989). Propast Zapada, III tom. Beograd: INP Književne novine.

\section{Đorđe N. Kebara}

\section{DECONSTRUCTION OF HISTORIOGRAPHY AND IDEOLOGICAL THOUGHT IN THE NOVEL THE CYCLIST CONSPIRACY OF SVETISLAV BASARA}

\begin{abstract}
Summary
The aim of this study is to disclose the principles and strategies in constructing the historiography theme in the novel. We consider the parody and metafiction construction as the main characteristics of its historiographic thinking. Basara's narrative strategy centers on the undermining of ideological systems, the negation of hierarchy and the abolition of institutional thinking, thus establishing a critical attitude towards historically based thinking. The author of the Cyclist Conspiracy assumes a metafictional world, constructed at the crossing of the intertext. The novel itself is presented as a collection of texts, a magazine or a journal. The prevailing method is not only the undermining of the ruling systems but also of one's own historic testimony. The assumed model of the world is one of a chaotic structure which is opposed to the false (institutional) historiographic consciousness that masks the truth by creating a phantom world, turning it into a simulacra. In that respect, a frequent metaphor is that of mirrors.
\end{abstract}

Key words: historiography, metafiction, intertext, plurality of texts, institution, the truth, simulacra, a mirror 